\title{
Two episodes of granitoids in the Chinese Altai, Central Asian Orogenic Belt: Records for tectonic transition from post- collision to intraplate settings
}

\author{
ZHENGFAN LIN $^{1,2}$, CHAO YUAN ${ }^{1}$, MiN SUN ${ }^{2}$, YUNYING \\ ZHANG $^{2}$
}

${ }^{1}$ State Key Laboratory of Isotope Geochemistry, Guangzhou Institute of Geochemistry, Chinese Academy of Sciences, Guangzhou 510640, China (linzhengfan@gig.ac.cn)

2 Department of Earth Sciences, The University of Hong Kong, Pokfulam Road, Hong Kong, China (zyy518@hku.hk)

Tectonic transition from post-collision to intraplate settings is a basic process in orogenic belts. To characterize such a transition in the Chinese Altai, an integrated study on Permian to Triassic granitoids was conducted. Zircon $\mathrm{U}-\mathrm{Pb}$ dating reveals that two phases of granitoids could mirror such a tectonic transition, namely the early Permian (291-286 Ma) and late Triassic (216-209 Ma) granitoids. Granitoids of both two phases show high $\mathrm{SiO}_{2}$, low $\mathrm{Mg} \#$, low $\mathrm{Cr}$ and $\mathrm{Ni}$, and variable $\mathrm{Sr}-\mathrm{Nd}-\mathrm{Hf}$ isotopes, all of which suggest a multiple crustal origin. In general, the Triassic granitoids exhibit similar $\varepsilon \mathrm{Nd}(\mathrm{t})$ but relatively higher $\varepsilon \mathrm{Hf}(\mathrm{t})$ values than those of the Permian granitoids. Moreover, the Triassic granitoids have relatively higher ASI and more variable $\mathrm{Al}_{2} \mathrm{O}_{3} / \mathrm{TiO}_{2}$, $\mathrm{CaO} / \mathrm{Na}_{2} \mathrm{O}, \mathrm{Rb} / \mathrm{Sr}$ and $\mathrm{Rb} / \mathrm{Ba}$ values than those of the Permian ones, suggesting that the Triassic magmatic sources were much variable and complicated with higher proportions of sediments. By integrating regional data, it is found that from early Permian to Triassic, the $\mathrm{SiO}_{2}, \mathrm{Na}_{2} \mathrm{O}+\mathrm{K}_{2} \mathrm{O}$ and Th contents, ASI and ${ }^{87} \mathrm{Sr} /{ }^{86} \mathrm{Sr}, \mathrm{Al}_{2} \mathrm{O}_{3} / \mathrm{TiO}_{2}, \mathrm{Rb} / \mathrm{Sr}$ and $\mathrm{Rb} / \mathrm{Ba}$ values for the felsic rocks gradually increase, implying more and more strongly reworking of continental crust. Also, the $\mathrm{Rb}, \mathrm{Y}+\mathrm{Nb}$ and $\mathrm{Yb}+\mathrm{Ta}$ contents for felsic rocks increase progressively from early Permian to Triassic, demonstrating a geodynamic transition from syn/post-collision to intraplate settings.

Acknowledgement: This work was financially supported by the National Science Foundation of China (41603030, 41973021) and the Hong Kong RGC research projects (17303415, 17302317). 